Abdusalam Drah ${ }^{1}$, Jelena D. Rusmirović ${ }^{2}$ Milena

Milošević ${ }^{1}$, Mustafa Kalifa ${ }^{1}$, Ivana Stojiljković ${ }^{3}$,

Milica Rančić ${ }^{3}$, Aleksandar D. Marinković ${ }^{1 *}$

${ }^{1}$ University of Belgrade, Faculty of Technology and Metallurgy,

Belgrade, Serbia, ${ }^{2}$ University of Belgrade, Innovation center, Faculty

of Technology and Metallurgy, Belgrade, Serbia, ${ }^{3}$ University of

Belgrade, Faculty of Forestry, Belgrade, Serbia

Scientific paper

ISSN 0351-9465, E-ISSN 2466-2585

UDC:66.096.097:65.011.4

doi:10.5937/ZasMat1604605D

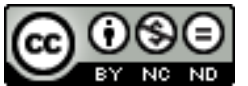

Zastita Materijala 57 (4)

$605-612(2016)$

\title{
Techno-economic analysis of unsaturated polyester production from waste PET
}

\begin{abstract}
Unsaturated polyester resins (UPe) were synthesized from maleic anhydride and products of glycolysis, obtained by polyethylene terephthalate (PET) depolymerization with dipropylene glycol (DPG) in the presence of tetrabutyl titanate catalyst. Waste PET glycolyzed product and UPes were characterized by FTIR and NMR spectroscopy, elemental analysis, acid value (AV), hydroxyl value (HV) and iodine value. Nanocomposites, based on unsaturated polyester resins and hexamethyldisilazane modified silica nanoparticles, were prepared with intention to show one of valuable applicative commercialization of UPe resin. In order to determine potential of the possible implementation of developed new technology for UPe production some aspect of technoeconomic analysis was analyzed. Economic potential/benefit and process profitability of the presented technology was based on the use of recycled raw input materials, i.e. waste PET, which is one of the most effective ways to save natural resources, protect the environment, and save money. Principles of green economy was incorporated in the results of developed UPe production technology which is related to both environmental protection and profitability achievement with no additional negative impact to environment, i.e. pollution decrease without negative effect of implemented technology.
\end{abstract}

Keywords: unsaturated polyester, modified silica, nanocomposite, profitability, green economy

\section{INTRODUCTION}

Poly(ethylene terephthalate) (PET) is a semicrystalline, thermoplastic polyester which possesses good mechanical properties and a high transparency. PET packages consumption has reached extremely high values that further contributes to increase of the amount of non-renewable waste on landfills. From the newest report of the packaging market analysis, it can be seen that the global PET packaging consumption of the period 2014-2019 will grow to over 20 Mt (4.6 \%) by 2019 [1]. The increase of the greenhouse gas emission and potential energy underutilization represent the main ecological problems which result in growing needs for plastic recycling [2,3]. Waste PET recycling can be done by alternative application of the following processes: re-extrusion (primary), mechanical (secondary), chemical (tertiary) and energy recovery (quaternary) [4].

\footnotetext{
${ }^{*}$ Corresponding author: Aleksandar Marinković E-mail: marinko@tmf.bg.ac.rs

Paper received: 28. 08. 2016.

Paper accepted: 18.09.2016.

Paper is available on the website: www.idk.org.rs/journal
}

Chemical recycling, as well as reusing of polymers is very important from the point of the reduction of pollution as an economical alternative which reduces the cost of simple plastic disposal [5]. Due the presence of the ester functional group, PET can be subjected to depolymerization with various reagents, whereby the cleavage of the macromolecular chains to lower molecular weight product could be controlled. The chemical recycling of PET can be divided into processes of: hydrolysis, alcoholysis, glycolysis, aminolysis and other procedures applicable for production of oligomeric/monomeric product of different functionalities depending on the reagent used [6-8].

Unsaturated polyesters (UPes) are one of the most widely used thermosetting resins for the fabrication of glass-reinforced plastics and polymer composites [9-11]. Due to their wide application which includes following areas: reinforced plastic laminates, electrical components, sheet molding compounds and pipes; the UPe market has huge economic potential. By the addition of silica nanoparticles in polymer matrix, a significant improvement of physico-mechanical and thermal properties of nanocomposite materials could be 
obtained [12-14]. Modification of silica nanoparticles proved to be a good alternative to improve nanofiller dispersion, stability and compatibility with the polymer matrix by the strong interaction between reinforcements and the polymer matrix [15]. Additionally, significant improvement of dynamic-mechanical properties could be achieved, at low level of nanofiller addition, by tailoring of nanofiller surface modification.

Using recyclable raw materials and optimizing the UPe production process could significantly contribute to market competitiveness with similar products obtained from commercial resources. Substitutions of commercial raw materials with ones obtained by waste PET depolymerization, achieved by performing trans-esterification reaction using various reactants, such as water, acids or bases, alcohols, amines and glycols with or without purification, used for the synthesis of a variety of materials such as UPe contribute to positive techno-economic indicators of such production processes [16].

Although many of UPe production technologies are examined and described, and applied in practice, there is still need for their improvement or development of new ones. Such conclusions are based on the state-of-the-art technology survey and assessments, consideration on upgrading of existing technology and development of new ones with critical analysis of the progress toward technical goals, feasibility and compliance with the law. The cost analysis of the production of newly synthesized UPe and developed technology are key criteria that must be considered at decisive point before continuation of the study at pilot and full-scale level of application [17,18].

In that context, the aim of this work was related to definition of optimal UPe production technology based on waste PET glycolysis products and UPe/silica nanocomposite material. UPes were synthesized from di-hydroxy functional products, obtained by different methods of catalytic glycolysis of PET waste with dipropylene glycol (DPG), and maleic anhydride. In order to evaluate the commercial viability of newly developed UPe production technology, the preliminary techno-economic analysis was performed. From the aspect of present study, the most important elements of cost analysis were selected to be raw materials and operational cost. Also, hybrid composite materials were prepared form UPes and chemically modified silica nanoparticles in order to present applicability and commercial value of UPe and related products.

\section{EXPERIMENTAL PART}

Experimental work included technology development for production of UPe and nanocomposite based on those UPes and hexamethyldisilazane modified silica as reinforcing agent. In general, whole process included four steps:

a) Production and purification of the glycolysis product based on waste PET and dipropylene glycol (DPG),

b) Production of unsaturated polyesters based on waste PET glycolizates

c) Production of nanocomposite materials based on UPes and modified silica nanoparticles

d) Techno-economic analysis of UPe production

\subsection{Materials}

PET waste, collected from soft drink bottles, was flaked into small pieces (app. $0.5 \times 0.5 \mathrm{~cm}$ ) and washed with a detergent, ethanol and dichloromethane to remove any trace of impurities and residual adhesives. DPG (a mixture of 4-oxa2,6-heptandiol, 2-(2-hydroxy-propoxy)-propan-1-ol, and 2-(2-hydroxy-1-methyl-ethoxy)-propan-1-ol), styrene, tetrabutyl titanate (TBT), xylene (mixture of 1,2-, 1,3- and 1,4-dimethyl- benzene), and dichloromethane (DCM) were purchased from Fluka. Toluene, pyridine, tetrahydrofuran (THF), 2butanone peroxide (methyl ethyl ketone peroxide; MEKP), cobalt octoate (Co-oct), $m$-xylene, maleic anhydride (MA) and hydroquinone (HQ) were obtained from Sigma-Aldrich. All chemicals were used as received without further purification. Fumed silica Aerosil R812S was kindly provided by Evonik. Aerosil ${ }^{\circledR}$ R812S is hydrophobic fumed silica after treated with HMDS (hexamethyldisilazane) with a surface area of $220 \pm 25 \mathrm{~m}^{2} / \mathrm{g}$.

\subsection{PET glycolizate production}

PET waste depolymerization was performed in a four-necked round bottom reactor by glycolysis with DPG by classical and ethylene glycol (EG) azeotropic removal method previously described in detailed [15]. The following two procedures were applied:

a) Classical method - $92.0 \mathrm{~g}$ of purified, dried and chopped PET $(0.474 \mathrm{~mol}), 92.0 \mathrm{~g}$ of DPG $(0.686 \mathrm{~mol})$ and $0.28 \mathrm{ml}$ of TBT catalyst were charged in four-necked round bottom reactor equipped with a mechanical stirrer, reflux condenser, thermometer, and a nitrogen inlet tube. The reaction mixture was maintained at $210-220^{\circ} \mathrm{C}$ providing efficient mixing for $6 \mathrm{~h}$ in an inert atmosphere. After completion of the glycolysis, all reaction mixture was dissolved in DCM $(200 \mathrm{ml})$ and washed two times with $150 \mathrm{ml}$ of distilled water in order to remove excess of alcohols. Afterwards, the product was filtered and dried in an oven at $90^{\circ} \mathrm{C}$ for $24 \mathrm{~h}$, and subsequently in a vacuum oven (5 mbar) at $80^{\circ} \mathrm{C}$ for $3 \mathrm{~h}$. The obtained product was denoted as DPG. 
b) Ethylene glycol (EG) azeotropic removal method - This method was conducted in an analogous procedure to method 2.2 a) with the following modification: after $3 \mathrm{~h}$ of glycolysis, DeanStark water separator was assembled in order to perform azeotropic distillation using $m$-xylene as the agent for heterogeneous removal of reaction product EG until no separation of EG was noticed. This product was used without further purification.

\subsection{Production of unsaturated polyesters (UPeN) \\ based on PET product glycolysis}

The procedure of UPeN production has recently been described [15]. After the glycolysis (method 2.2), the reaction mixture was cooled to 90 ${ }^{\circ} \mathrm{C}$ and $\mathrm{MA}(59.0 \mathrm{~g}, 0.60 \mathrm{~mol})$ and $\mathrm{HQ}(0.02 \mathrm{~g})$ were added under inert atmoshere. The mixture was heated at $115{ }^{\circ} \mathrm{C}$ for $1 \mathrm{~h}$. Afterwards, continuous temperature increase was achieved at a heating rate of $15^{\circ} \mathrm{C} / \mathrm{h}$. When the reaction mixture temperature reached $150 \stackrel{\circ}{\circ}$, xylene $(5.5 \mathrm{~g}, 3 \mathrm{wt}$. \% with respect to the reaction mixture) was added to provide water removal by binary azeotrope, assuring in this manner a driving force for reaching the end-point of reaction at $210 \stackrel{\circ}{\circ}$. After the completion of the reaction, the obtained resin was cooled to $120^{\circ} \mathrm{C}, 0.02 \mathrm{~g}$ hydroquinone in $0.2 \mathrm{ml}$ of absolute ethanol was added. Subsequently, vacuum distillation (water pump) was carefully applied for $1 \mathrm{~h}$ to remove low boiling compounds present in the final product. Then, the resin was cooled down to $90{ }^{\circ} \mathrm{C}$ and styrene (40 wt.\%) was added, followed by mixing to ensure homogeneity of the product. In the case when the glycolysis product obtained by classical method was used (exp. 2.2a), the obtained UPe was named UPe1, while in the case when the glycolysis product obtained by EG azeotropic removal method was used (exp. 2.2b), the product was named UPe2.

\subsection{Preparation of nanocomposites based on UPeN and fumed silica}

The nanocomposites, UPeN/SiO${ }_{2} \mathrm{R} 812 \mathrm{~S}(\mathrm{n})$, were obtained by processing of appropriate amounts of binder, UPeN resin and nanofillers, Aerosil R812S, carefully blended (homogenized) for $30 \mathrm{~min}$. Index $\mathrm{N}$ designates $\mathrm{UPe}$ resin (described in exp. 2.3)), and index (n) designates percent of Aerosil R812S addition: 0.1 (a), 0.25 (b), 0.5 (c), 1.0 (d) and 2.0 (e) wt.\%. Homogenization of fumed silica, Aerosil R812S, with UPeN (60 wt.\% in styrene) was achieved by using both modified laboratory homogenizer and ultrasonic bath (Bandelin electronic, Berlin, Germany, power 120 $W$, frequency $35 \mathrm{kHz}$ ). The pure UPeN (60 wt.\% in styrene) and nanocomposites $\mathrm{UPeN} / \mathrm{SiO}_{2} \mathrm{R} 812 \mathrm{~S}(\mathrm{n})$ were cured using MEKP (1 wt.\%) as initiator and Co-oct (0.5 wt.\%) as accelerator. Obtained uncured polymeric dispersion was homogenized at high speed, $800 \% \mathrm{~min}$, and loaded in PTFE mould, allowing completion of the curing reactions [15]. The technological scheme of the UPe and nanocomposite production is given at Scheme 1 .

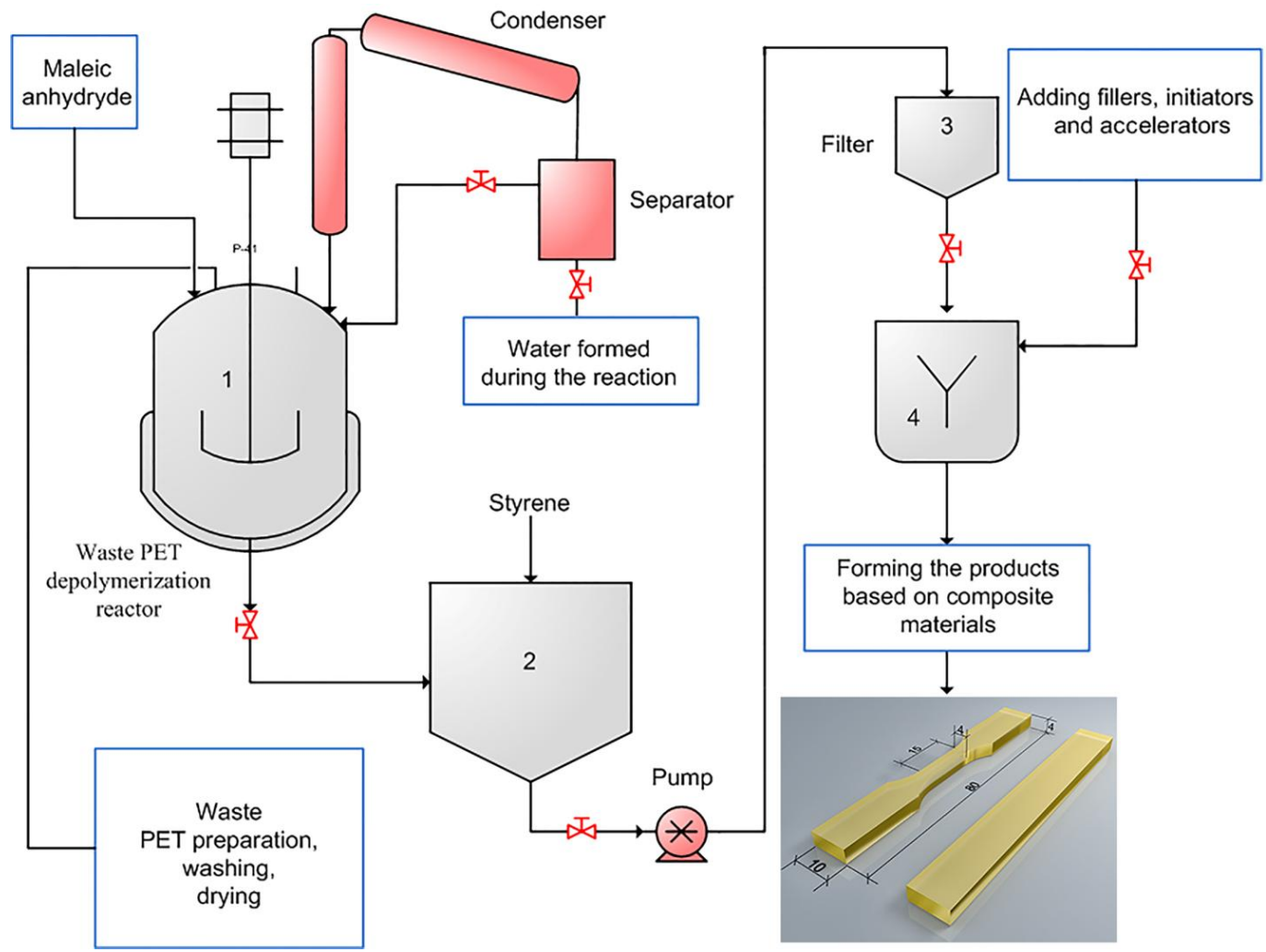

Scheme 1 - Schematic overview of the UPe and nanocomposite production technology 


\subsection{Characterization methods}

FTIR spectra were recorded on Bomem MB102 spectrometer, within a range of $400-4000 \mathrm{~cm}^{-1}$, at a resolution of $4 \mathrm{~cm}^{-1} .{ }^{1} \mathrm{H}$ and ${ }^{13} \mathrm{C}$ NMR spectra were recorded in deuterated chloroform $\left(\mathrm{CDCl}_{3}\right)$, using a Varian-Gemini 200 spectrometer at 200 $\mathrm{MHz}$ for the ${ }^{1} \mathrm{H}$ NMR and $50 \mathrm{MHz}$ for the ${ }^{13} \mathrm{C}$ NMR spectra. Elemental analyses were performed using a Vario EL III Elemental analyzer.

The hydroxyl value (HV) was determined by the use of a conventional acetic anhydride/pyridine method (ISO 4326:1992) [19]. The acid value (AV) was evaluated according to ASTM D3644 [20]. Number average molecular weight was calculated according to the following eq. (1):

$$
M_{n}=\frac{2 \cdot 56100}{A V+H V}
$$

lodine value was determined by the Wijs method. The viscosity measurement of the UPeN, $60 \mathrm{wt} . \%$ styrene solution, was carried out at $25^{\circ} \mathrm{C}$, using Ford viscosity cup 4 (ASTM D1200) [20]. The gel time of the samples was determined from the cure exotherm which was measured according to ASTMD 2471-99 [21]. Uniaxial tensile measurements of standard cured samples (ASTM D882) [22] were performed using an $A G-X$ plus Universal testing machine, Shimadzu. All tests were performed at room temperature adjusted at crosshead speed of $0.5 \mathrm{~mm} / \mathrm{min}$.

\section{RESULT AND DISSCUSION}

\subsection{Characterization of waste PET glycolizates and UPe}

Analysis of FTIR spectra of the obtained glycolized products and UPeN gave information about the functional groups present on the polyester chains. The FTIR spectra of the glycolyzed product (method 2.2) and UPe1 (method 2.3) are shown in Figure 1. The broad band, in the spectrum of the glycolized product (DPG), observed at $3529 \mathrm{~cm}^{-1}$ was attributed to the $\mathrm{OH}$ group stretching vibration, while aromatic $\mathrm{C}-\mathrm{H}$ stretching vibration could be observed as shoulder at $\approx 3056 \mathrm{~cm}^{-1}$. Stretching vibrations, asymmetric and symmetric, of methyl and methylene groups, present in both aliphatic moieties of modified silica and alcohol ester residue of DPG appeared in the region $2955-2869 \mathrm{~cm}^{-1}$. The band at $1725 \mathrm{~cm}^{-1}$ was assigned to the stretching vibration of the ester carbonyl group present in DPG. The main absorption bands between $1300 \mathrm{~cm}^{-1}$ and $1100 \mathrm{~cm}^{-}$ 1 originate from asymmetric and symmetric stretching of $\mathrm{C}-\mathrm{O}$ group vibrations. In the FTIR spectrum of UPe1 resin, new bands at $1640 \mathrm{~cm}^{-1}$ and $981 \mathrm{~cm}^{-1}$ correspond to the $\mathrm{C}=\mathrm{C}$ stretching (skeletal) vibration of the benzene ring and out of plane bending vibrations of 1,2-trans disubstituted vinyl group, present in fumaric acid fragment, respectively. Sharp and moderate band at $730 \mathrm{~cm}^{-1}$, observed in the spectra of DPG and UPe1, corresponded to skeletal deformation, $\mathrm{Y}(\mathrm{CH})$, vibration of benzene ring present in the fragment of ester of terephtalic acid.

Results of ${ }^{1} \mathrm{H}$ and ${ }^{13} \mathrm{C}$ NMR analysis of UPe1 are as follows:

${ }^{1} \mathrm{H}$ NMR $\left(\mathrm{CDCl}_{3}\right): 0.96-1.58\left(m, 12 \mathrm{H}, 4 \times \mathrm{CH}_{3}\right), 3.98-$ $4.67\left(m, \quad 4 \mathrm{H}, \quad 2 \times \mathrm{CH}_{2}\right), \quad 5.18-5.46(m, \quad 4 \mathrm{H}$, $\left.2 \times \mathrm{COOCH}_{2}\right), 6.95(\mathrm{~s}, 4 \mathrm{H}$, fumaric moiety), $8.08(\mathrm{~s}$, $\left.4 \mathrm{H}, \mathrm{H}_{\mathrm{Ph}}\right) ;{ }^{13} \mathrm{C} \mathrm{NMR}\left(\mathrm{CDCl}_{3}\right): 16.2$ and $19.5\left(4 \mathrm{xCH}_{3}\right)$, 62.7, 65.7-66.7, 69.2-70.3, 76.4-77.6 $\left(\mathrm{CH}_{2}\right.$ carbons in DPG moiety), 127.7-128.4 $\left(4 \times \mathrm{C}_{\mathrm{Ph}}\right), 133.7(\mathrm{O}=\mathrm{C}-$ $\mathrm{HC}=\mathrm{CH}-\mathrm{C}=\mathrm{O}), 133.8(2 \times \mathrm{Ph}(\mathrm{C})-\mathrm{COO}), 164.1$ and $164.4(\mathrm{O}=\mathrm{C}-\mathrm{HC}=\mathrm{CH}-\mathrm{C}=\mathrm{O}), \quad 164.9$ and 165.3 (2xPhCOO). Similar results were found for UPe2.

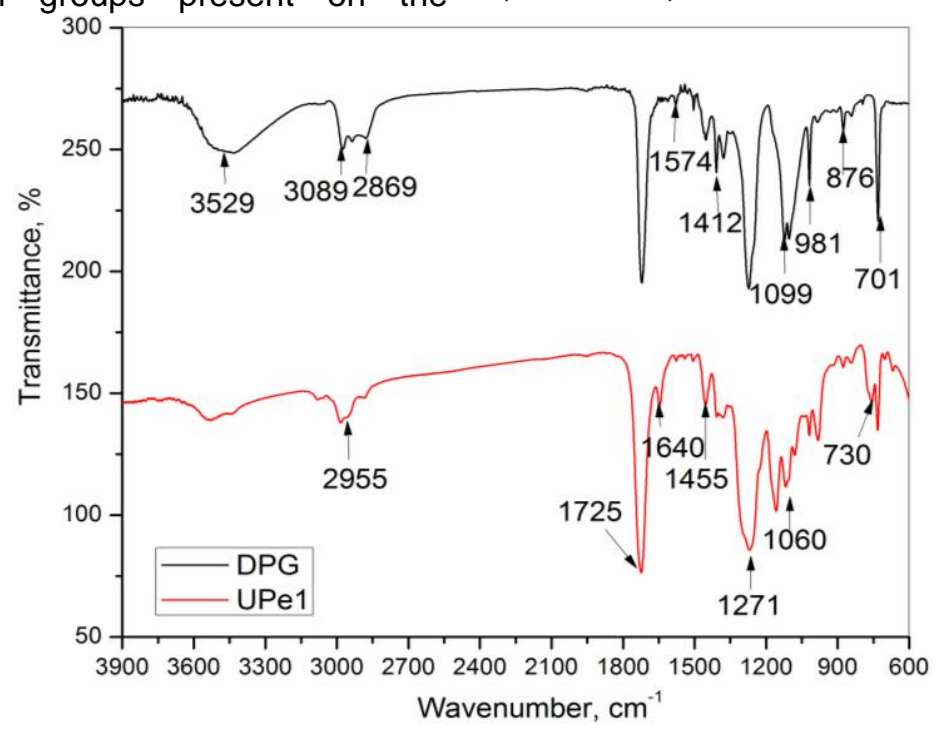

Figure 1 - FTIR spectra of the glycolyzed product (named DPG; classical method) and UPe1 
Acid value $(A V)$, hydroxyl value $(H V)$, iodine value $(I V)$, molecular weight $\left(M_{n}\right)$ and viscosity of UPeN are shown in Table 1.

From these results (Table 1), it could be observed that synthesized UPeN have similar $A V$, $H V, M_{n}$, iodine value and viscosity. Slightly higher values of $A V, H V$ and viscosity are observed for
UPe1, while $M_{\mathrm{n}}$ and iodine value are slightly lower. This structural similarity indicates that the PET waste depolymerization method had no significant influence on UPeN characteristics, hence from the techno-economic aspects, better method is the one that includes less mechanic operations as well as equipment (classical method).

Table 1 - The AV, HV, $M_{n}$ and iodine value and viscosity of the synthesized UPe

\begin{tabular}{|c|c|c|c|c|c|}
\hline Sample & $\mathrm{AV}, \mathrm{mgKOH} / \mathrm{g}$ & $\mathrm{HV}^{\mathrm{a}}, \mathrm{mgKOH} / \mathrm{g}$ & $\mathrm{Mn}^{\mathrm{b}}, \mathrm{g} / \mathrm{mol}$ & $\mathrm{IV}$ & Viscosity, $^{-1}$ \\
\hline UPe1 & 12.4 & 30.9 & 2591 & 42 & 85 \\
\hline UPe2 & 11.2 & 29.6 & 2750 & 48 & 88 \\
\hline
\end{tabular}

${ }^{a}$ Theoretical HV value was determinate relying on the number of hydroxyl group of DPG, recalculated to the molar mass of the product of glycolysis. ${ }^{b} M_{n}$ values were calculated according to the equation (1).

\subsection{Mechanical testing of UPeN based nanocomposites}

With the aim to investigate influence of content of incorporated hexamethyldisilazane modified silica nanoparticles on the mechanical properties of the produced nanocomposites based on UPe, the mechanical testing has been done [15]. The values of stress at break $\left(\sigma_{\mathrm{b}}\right)$ and elongation at break $\left(\varepsilon_{\mathrm{b}}\right)$ cured UPe1 and UPe1/SiO2R812S(n) samples are shown in Figure 2.
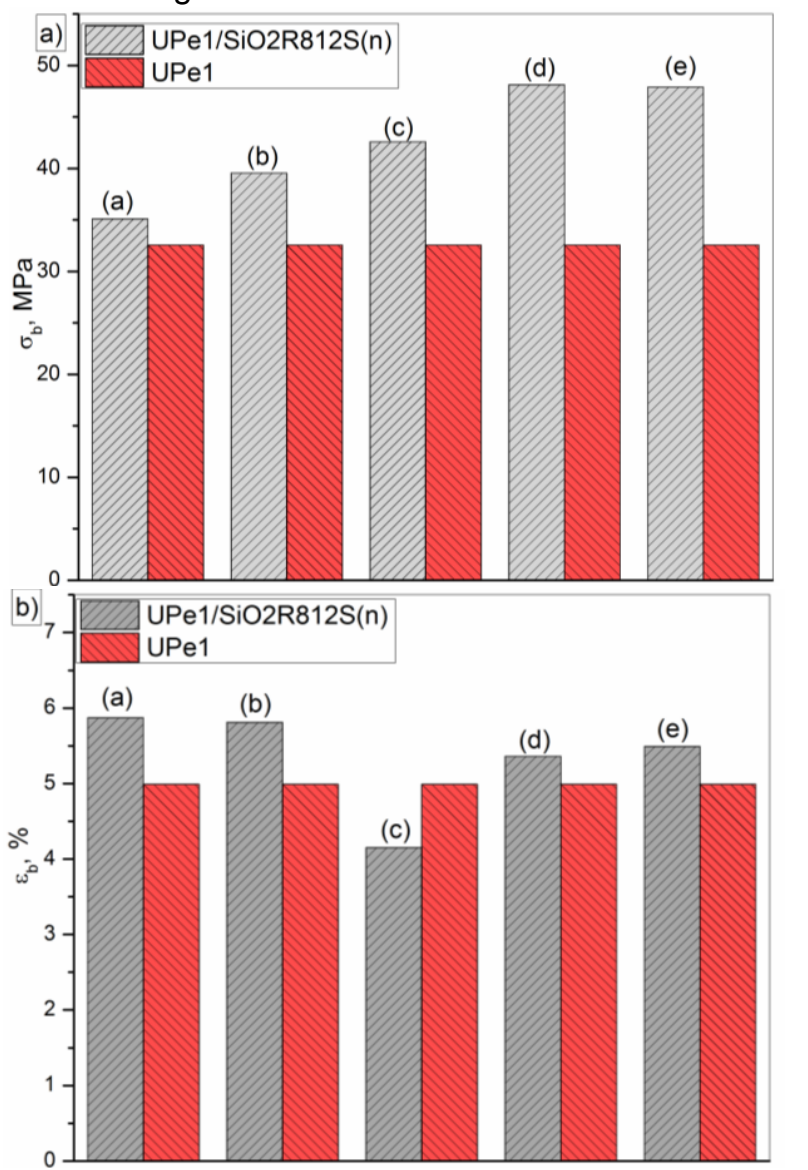

Figure 2 - The values of a) stress at break $\left(\sigma_{b}\right)$ and $b)$ elongation at break $\left(\varepsilon_{b}\right)$ of cured UPe1 and UPe1/SiO2R812S(n)
Mechanical testing results indicate that stress at break of all cured nanocomposites is higher than for pure cured UPe1 and increases with increasing silica content up to the 1 wt.\% in UPe1/SiO2R812S(n) and after that, it was constant or slightly reduced. Incorporation of more than 2 wt.\% of modified silica nanoparticles makes more difficult dispersion in polymeric matrix [15]. Similar results were found for cured UPe2 and UPe2/SiO2R812S $(n)$ with mainly higher $\sigma_{\mathrm{b}}$ values in the range of $1.4-5.8 \%$, and the largest reinforcing effect is found at $1 \mathrm{wt} \%$ of SiO2R812S addition, i.e. for UPe2/SiO2R812S(d) nanocomposite, somewhat higher value of 52.6 MPa was obtained.

In the Characterization Section (3.1), the comparative analysis of the structural characterization results of the obtained UPeN using process technology by classical (exp. 2.2a) and EG azeotropic removal method (exp. 2.2b) was given. Due to simpler procedure of the glycolyzed product synthesis, obtained according to method 2.2b), and improved mechanical properties of UPe2/SiO2R812S(n) derived nanocomposites, the presented techno-economic analysis was related to UPe2 resin production.

\subsection{Techno-economic analysis of UPe2 resin production}

The conceptual design of processing plants for nanocomposite materials was based on silica nanoparticles and UPe obtained from waste PET (Scheme 1). The techno-economic analysis is a complex procedure and generally includes two categories: capital and maintenance/operational (MO) cost. Design of technology provides data necessary for calculation of the values of capital investment (equipment, construction, installation, etc.). MO cost elements of different UPe technologies such chemicals, labor and energy cost are of different values in techno-economic analysis. Due to this, selection of the most influential factors, without sacrificing validity of assessments, was made. 
Techno-economic analysis of the UPe2 production, performed by calculation of monthly fixed and variable costs, as well as the breakeven point, was done with the aim of determination of the profitability and economic benefit of the implemented UPe2 resin production. Profitability is one of the main objectives of the production success and realization of production. The entire study was done for a productive plant of $5.6 \mathrm{t} /$ day (2055 t/year). Planed capacity is in accordance with the Serbian market needs. Monthly fixed and variable costs, as well as breakeven point are presented in Table 2.

Table 2 - Monthly fixed and variable capital costs of UPe production

\begin{tabular}{|l|c|c|c|}
\hline \multicolumn{2}{|c|}{ Monthly fixed costs $(€)$} & \multicolumn{2}{c|}{ Monthly variable costs (5.6 t/day), $€$} \\
\hline \multicolumn{1}{|c|}{ Constructions } & & Raw materials ${ }^{\star *}$ & 207690 \\
\hline Funds for the operation & 1776 & Fuels & 170 \\
\hline Light energy & 712 & Electric power for the reactor & 3000 \\
\hline Workforce & 8000 & Transport & 1000 \\
\hline Sales and marketing expenses & 1500 & Packaging & 10100 \\
\hline Other fixed expenses & 350 & & \\
\hline Bookkeeping and maintenance & 1000 & & \\
\hline Research and development & 1500 & & 221960 \\
\hline Total fixed costs (€) & $\mathbf{1 5 2 5 4}$ & Total variable costs (€) & 237214 \\
\hline The breakeven (monthly turnover) $(\boldsymbol{\epsilon})$ & & & 7907 \\
\hline Daily turnover (profitability) $(\boldsymbol{\epsilon})$ & & & 10325 \\
\hline Daily turnover (planned) $(\boldsymbol{\epsilon})$ & & & 72540 \\
\hline Profit per month & & & 300000 \\
\hline Investment in business & Own funds & & 200000 \\
\hline
\end{tabular}

${ }^{*}$ REACTOR $279240 €$; two tanks $(\mathrm{V}=200 \mathrm{t}) 80000 €$; pump $2000 €$; decanting tank $2000 €$; transformer substation $2000 €$; cooling tower $10000 €$; fire protection $50000 €$; waste water treatment $10000 €$; compressor $20000 €$; two tanks $(V=100 t) 30000 €$; centrifugal pump $4000 €$ (Total $509240 €)$; period of amortization of operation funds - 20 years; period of amortization of buildings - 50 years. ${ }^{* *}$ Raw materials: Waste PET - $400 € / t$; DPG - $2000 € / t$; AMK - $1300 € / t$.

Economic benefit of the implementation of UPe technology refers to the input of raw material such as PET glycolizates which contribute to reduced cost of the final product. In Table 2 all the purchase cost of the equipment, employed and raw is shown. Total summarized monthly fixed and variable costs for UPe production amount $237214 €$. The most relevant economic indicators, as well as a summary of the previous cost were used to calculate the breakeven point of UPe technology, and on that basis, it was obtained that $7907 €$ of daily earnings is necessary to achieve polyester profitability of the UPe resin production. Predicted selling price of the product has variations with respect to commercial raw materials used in synthesis UPe resin. Average price over time amounts about $1.84 € / \mathrm{kg}$. Those production capacity makes 10325 $€$ daily earnings and $72540 €$ monthly profit, respectively. Cumulative net value of UPe production for period of 18 months is shown in Table 3.

Table 3 - Cumulative net of UPe production for period of 18 months ( $€$ )

\begin{tabular}{|c|c|c|c|c|c|c|}
\hline & I quarter & II quarter & III quarter & IV quarter & V quarter & VI quarter \\
\hline Income & 60968.9 & 677423.3 & 752692.5 & 836325 & 929250 & 929250 \\
\hline Fixed costs + variable costs & 447171 & 513759 & 580347 & 646935 & 713523 & 713523 \\
\hline \multicolumn{7}{|c|}{ Financing costs } \\
\hline Profit & 447171 & 513759 & 580347 & 646935 & 713523 & 713523 \\
\hline $\begin{array}{l}\text { Reduction of financial } \\
\text { obligations }\end{array}$ & 447171 & 513759 & 580347 & 646935 & 713523 & 713523 \\
\hline Cash flows & 447171 & 513759 & 580347 & 646935 & 713523 & 713523 \\
\hline Cash balance & 447171 & 513759 & 580347 & 646935 & 713523 & 713523 \\
\hline Total cash flows & 447171 & 513759 & 580347 & 646935 & 713523 & 713523 \\
\hline Net present value (NVP) & 126643 & 125270 & 130995 & 144176 & 165196 & 161955 \\
\hline Total net present value & 357835 & & & & & \\
\hline Invested assets & 300000 & & & & & \\
\hline Profit & 554237 & & & & & \\
\hline
\end{tabular}


From the conceptual design of the UPe technology production it could be concluded that positive NVP values was found for whole period under study (from I to VI quarter). Cumulative NVP values (Table 3 ) amount $126643 €$ for 18 month which proves the economic viability of the presented UPe technology. Consideration of the total fixed and variable monthly cost related to described UPe technology shows profit in each quarter. However, the presented technology appears to be acceptable alternative for the UPe production due to many comparative benefits: environmental-friendly technological processes and no secondary by-product was generated.

Comparative analysis of the cost of commercial UPe based on DPG and MA, available on Serbian market (Table 4), are in the range from $>2 € / \mathrm{kg}$ and UPe2 resin obtained from waste PET in this work is somewhat lower $(\approx 1.84 € / \mathrm{kg})$. The differences in capital cost for the UPe of similar properties could be considered to be approximately negligible concerning contribution to techno-economic analysis, and thus, to the main elements which contribute to designing of UPe production. Also, one more economic benefit arising from UPe production, more precisely, from waste PET azeotropic glycolysis due to the release of equimolar amount of EG. This means that during the production of one batches/day (5.6 t/day), approximately $0.68 \mathrm{t}$ of $\mathrm{EG}$ will be separated. $\mathrm{EG}$ is valuable product which can be used for commercial synthesis of PET, either for the production of EG as a solvent and preservative used in many commercial and industrial applications including antifreeze and coolants for gas compressors, heating, ventilating, and air-conditioning systems, and ice skating rinks.

Table 4 - Monthly fixed and variable capital costs of commercial UPe production

\begin{tabular}{|l|c|}
\hline \multicolumn{2}{|c|}{ Monthly fixed and variable costs (5.6 t/day), $€$} \\
\hline Raw materials & 307260 \\
\hline Fuels & 170 \\
\hline Electric power for the reactor & 3000 \\
\hline Transport & 1000 \\
\hline Packaging & 10100 \\
\hline Total variable costs $(\boldsymbol{\epsilon})$ & $\mathbf{3 2 1 5 3 0}$ \\
\hline Total fixed costs $(\boldsymbol{\epsilon})$ & $\mathbf{1 5 2 5 4}$ \\
\hline The breakeven (monthly turnover) $(\boldsymbol{\epsilon})$ & 336784 \\
\hline Daily turnover (profitability) $(\boldsymbol{\epsilon})$ & 11226 \\
\hline
\end{tabular}

The incorporation of hexamethyldisilazane modified silica nanoparticles, in amount of $1 \mathrm{wt} \%$, in UPe2 produces nanocomposite material with increased mechanical properties compared to neat cured UPeN (Section 3.2). Also, the influence of the modified silica (fiber-glass) content on the rheological and mechanical properties of the PET based nanocomposites caused high increase of the stress at break and tensile modulus [23]. In the other hand, from the techno-economical point of view silica addition contributes to the increase of the cost of product. Silica accounts for 1 wt.\% of the purchase cost of raw materials and its price is $1500 € / t$. Due to that, by recalculation of the cost of obtained nanocomposite, the increase of around 15 $€ / \mathrm{t}$ for $1 \mathrm{wt} . \% / \mathrm{t}$ nanosilica adidition has low influence on market price. This example shows that market value of UPe was validated and competitiveness of UPes at market, except for the lower price and product quality, was improved by broad assortment of possible market products based on UPe.

\section{CONCLUSION}

Environmental and economic benefits of recycling and reused of polymeric materials such as PET was evaluated in order to prevent pollution by reducing the need to harvest new raw materials, saving energy, reducing greenhouse gas emission that contribute to global climate change and saving money throught the lower cost of the waste raw materials. The aim of this study was to investigate the possibility and viability of polyester resin production technology based on chemical depolymerization of waste PET. From the structural similarity of UPeN resins, UPe1 and UPe2, and high-reinforcement effect in UPe based nanocomposites, the UPe2 production was designated as material of choice which offers better product properties, and also satisfy techno-economic criteria for implementation in a real production processes.

Positive NVP values for quarterly overview confirm that the presented UPe production technology is economically acceptable because of the positive contribution of lower expenses of plant and construction material, and waste material (waste PET) cost which dominated in a financial structure. The incorporating of hexamethyldisilazane modified silica nanoparticles in composite materials, in amounts of $1 \mathrm{wt} . \%$, contributes to improvement of physico-mechanical properties and has no significant influence on economic viability of presented technology.

\section{Acknowledgements}

The authors acknowledge financial support from Ministry of Education, Science and Technological development of Serbia, Project No. OI 172057.

\section{REFERENCES}

[1] Information on http://www.packagingnews.co.uk/ news/global-consumption-of-pet-packaging-forecast -to-grow-to-over-20m-tonnes-by-2019/ (accessed December 2014).

[2] A.M.Atta, M.E.Abdel-Raouf, S.M.Elsaeed, A.A. Abdel-Azim (2007) Mechanical characterization and chemical resistances of cured unsaturated polyester resins modified with vinyl ester resins based on recycled poly(ethylene terephthalate), Journal of Applied Polymer Science, 103(5), 3175-3182. 
[3] C.Lorenzetti, P.Manaresi, C.Berti, G.Barbiroli (2006) Chemical Recovery of Useful Chemicals from Polyester (PET) Waste for Resource Conservation: A Survey of State of the Art, Journal of Polymers and the Environment, 14, 89-101.

[4] F.Awaja, D.Pavel (2005) Recycling of PET, European Polymer Journal, 41, 1453-1477.

[5] S.M.Al-Salem, P.Lettieri, J.Baeyens (2009) Recycling and recovery routes of plastic solid waste (PSW): A review, Waste Management, 29, 26252643.

[6] P.Karayannidis, S.Achilias, D.Sideridou, N.Bikiaris (2005) Alkyd resins derived from glycolized waste poly(ethylene terephthalate), European Polymer Journal, 41, 201-210.

[7] G.Güçlü, M.Orbay (2009) Alkyd resins synthesized from postconsumer PET bottles, Progress in Organic Coatings, 65, 362-365.

[8] L.Bartolome, M.Imran, B.G.Cho, W. Al-Masry, D.H.Kim (2012) Recent developments in the chemical recycling of PET, Book Material Recycling - Trends and Perspectives, InTech, pp 65-84.

[9] A.Torlakoğlu, G.Güçlü (2009) Alkyd-amiono resins based on waste PET for coating applications, Waste Manage, 29 , 350-354.

[10] C.Varga, N.Miskolczi, L.Bartha, G.Lipóczi (2010) Improving the mechanical properties of glass-fibrereinforced polyester composites by modification of fibre surface, Materials and Design. , 31, 185-193.

[11] R.Sengupta, M.Bhattacharya, S.Bandyopadhyay, A.K.Bhowmick (2011) A review on the mechanical and eletrical properitis of graphite and modifiedgraphite reinforced polymer composite, Progress in Polymer Science, 36, 638-670.

[12] L.Guo, X.Xu, Y.Zhang, Z.Zhang (2014) Effect of functionalized nanosilica on properties of polyoxymethylene-matrix nanocomposites, Polymer Composites, 35, 127-136.

[13] L.Tong, Z.Pu, Z.Chen, X.Huang, X.Liu (2014) Effect of nanosilica on the thermal, mechanical, and dielectric properties of polyarylene ether nitriles terminated with phthalonitrile, Polymer Composites, 35, 344-350.

[14] Y.Li, C.Han, X.Zhang, J.Bian, L.Han (2013) Rheology, Mechanical Properties, and Biodegradation of Poly(e-caprolactone)/Silica Nanocomposites, Polymer Composites, 34, 1620-1628.

[15] J.Rusmirović, T.Radoman, E.Džunuzović, J.Džunuzović, J.Markovski, P.Spasojević, A. Marinković (2015) Effect of the modified silica nanofiller on the mechanical properties of unsaturated polyester resins based on recycled polyethylene terephthalate, Polymer Composites, in press, DOI 10.1002/pc.23613.

[16] S.Katoch, V.Sharma, P.P.Kundu (2010) Water sorption and diffusion through saturated polyester and their nanocomposites synthesized from glycolyzed PET waste with varied composition, Chemical Engineering Science, 65, 4378-4387.

[17] J.Dullius, C.Ruecker, V.Oliveira, R.Ligabue, S. Einloft (2006) Chemical recycling of post-consumer PET: Alkyd resins synthesis, Progress in Organic Coatings, 57, 123-127. [18] A.Hofland (2012) Alkyd resins: From down and out to alive and kicking, Progress in Organic Coatings, 73 (4), 274-282.

[18] ISO 4326(1992): Non-ionic surface active agents Polyethoxylated derivatives -Determination of hydroxyl value - Acetic anhydride method.

[19] ASTM D3644(2012): Standard Test Method for Acid Number of Styrene-Maleic Anhydride Resins.

[20] ASTM D1200(2014): Standard Test Method for Viscosity by Ford Viscosity Cup.

[21] ASTM D2471-99(2008): Standard Test Method for Gel Time and Peak Exothermic Temperature of Reacting Thermosetting Resins.

[22] ASTM D882(2009): Standard Test Method for Tensile Properties of Thin Plastic Sheeting.

[23] T.Pepper (2003) Polyester Resin, Ashland Chemical Company, Lexington, KY, 90.

\section{IZVOD}

\section{TEHNO-EKONOMSKA ANALIZA PROIZVODNJE NEZASIĆENIH POLIESTARA IZ OTPADNOG PET-A}

Nezasićene poliestarske smole (UPe) su sintetisane iz anhidrida maleinske kiseline i proizvoda glikolize, dobijenih depolimerizacijom poli(etilen tereftalata) (PET-a) sa dipropilen-glikolom (DPG) u prisustvu tetrabutil-titanata kao katalizatora. Proizvod glikolize otpadnog PET-a i UPe smole su okarakterisani pomoću FTIR i NMR spektroskopije, elementalne analize, kiselinskog (AV), hidroksilnog (HV) i jodnog broja. Nanokompoziti, bazirani na nezasićenim poliestarskim smolama i nanočesticama silicijum-dioksida modifikovanim heksametildisilazanom, pripremljene su sa namerom da se prikaže jedna od značajnih komercijalnih primena UPe smola. U cilju određivanja mogućnosti mogućih implementacija razvijenih novih tehnologija proizvodnje UPe smola, urađena je neki tehno-ekonomska analiza. Ekonomska korist i profitabilnost procesa prikazane tehnologije su zasnovani na primeni reciklaže sirovog materijala, otpadnog PET-a, što predstavlja jedan od najefektivnijih načina da se očuvaju prirodni resursi, zaštiti životna sredina i uštedi novac. Principi zelene ekonomije su ugrađeni u razvijenoj tehnologiji proizvodnje UPe smola, što se odnosi i na zaštitu životne sredine $i$ dostizanje profitabilnosti bez dodatnih negativnih uticaja na životnu sredinu, odnosno na smanjenje zagađenja bez negativnog uticaja na implementiranu tehnologiju.

Ključne reči: nezasićene poliestarske smole, modifikovani silicijum-dioksid, nanokompoziti, profitabilnost, zelena ekonomija.

Naučni rad

Rad primljen: 28.8.2016.

Rad prihvaćen: 18.09.2016.

Rad je dostupan na sajtu: www.idk.org.rs/casopis 